\title{
Advances in the treatment of rheumatoid arthritis
}

\section{Nancy Vivar and Ronald F. Van Vollenhoven*}

Address: Department of Medicine, Unit of Clinical Therapy Research in Inflammatory Diseases (ClinTRID), Karolinska University Hospital, D2:00, 17176 Stockholm, Sweden

* Corresponding author: Ronald F. Van Vollenhoven (Ronald.van.Vollenhoven@ki.se)

Fl000Prime Reports 2014, 6:3I (doi:10.12703/P6-3I)

All FI000Prime Reports articles are distributed under the terms of the Creative Commons Attribution-Non Commercial License (http://creativecommons.org/licenses/by-nc/3.0/legalcode), which permits non-commercial use, distribution, and reproduction in any medium, provided the original work is properly cited.

The electronic version of this article is the complete one and can be found at: http://fl $000 . c o m /$ prime $/$ reports $/ \mathrm{m} / 6 / 31$

\begin{abstract}
The intense pursuit of novel therapies in rheumatoid arthritis has provided physicians with an assorted set of biologic drugs to treat patients with moderate to severe disease activity. Nine different biologic therapies are currently available: seven inhibitors of pro-inflammatory cytokines (five targeting tumor necrosis factor [TNF], one interleukin [IL]-I and one IL-6), as well as a T- and a B-lymphocyte targeting agent. All these drugs have roughly similar efficacy profiles and are approved as first- or second-line therapy in patients who failed to respond to conventional disease-modifying anti-rheumatic drugs (DMARDs) and in most cases for first line use in rheumatoid arthritis as well. Despite the irrefutable clinical and radiological benefits of biologic therapies, there are still low rates of patients achieving stable remission. Therefore, the quest for new and more effective biologic therapies continues and every year new drugs are tested. Simultaneously, optimal use of established agents is being studied in different ways. Recently, the approval of the first small molecule targeting intracellular pathways has opened a new chapter in the treatment of rheumatoid arthritis. Other emerging treatment strategies include the activation of regulatory $T$ cells as well as new cytokine-targeting therapies.
\end{abstract}

\section{Introduction}

Rheumatoid arthritis is an autoimmune disease affecting approximately $1 \%$ of people in the developed world [1]. It is characterized by synovial inflammation and joint destruction, eventually inducing severe disability, if left untreated [2].

The international recommendations for the treatment of rheumatoid arthritis include DMARDs such as methotrexate as the main treatment approach, while biologic DMARDs are usually considered only when the former are not sufficiently effective [3].

Here, we provide an overview of currently available as well as emerging immunomodulatory therapies, biologic (Table 1) and targeted synthetic DMARDs, in rheumatoid arthritis. Such therapeutic strategies either target pro-inflammatory cellular products (cytokines), cellular receptors (cluster of differentiation or $[\mathrm{CD}]$ molecules) or intra-cellular pathways leading to the expression of pro-inflammatory molecules.

\section{Cytokine-targeting agents \\ Etanercept}

Etanercept, the first TNF inhibitor approved in 1998 for the use in rheumatoid arthritis, is a recombinant fusion protein, which links the soluble TNF receptor to the Fc portion of human Immunoglobulin $\mathrm{G}$ (IgG). It works as a decoy receptor, binding to soluble TNF and blocking the binding to its receptor. It has a short half-life (3-6 days), and is usually administered subcutaneously $50 \mathrm{mg}$ once a week or $25 \mathrm{mg}$ twice a week. The clinical efficacy of etanercept has been shown both as monotherapy [4] and in combination with methotrexate [5], the combination providing better results than methotrexate or etanercept alone [6].

Several recent studies have suggested that in patients with established rheumatoid arthritis who have achieved 
Table I. Overview of the currently available biologic DMARDs for the treatment of rheumatoid arthritis

\begin{tabular}{|c|c|c|c|c|c|}
\hline Name & Target & Format & Mechanism & Administration & $\begin{array}{l}\text { Approximate } \\
\text { half-life* }^{*}\end{array}$ \\
\hline Etanercept & TNF & $\begin{array}{l}\text { Recombinant human fusion } \\
\text { protein of the TNF receptor } \\
\text { and the Fc portion of } \operatorname{lgG} \mid \text {. }\end{array}$ & $\begin{array}{l}\text { Works as a decoy receptor. It } \\
\text { binds to soluble TNF, blocking } \\
\text { the binding to its receptor }\end{array}$ & $\begin{array}{l}\text { sc. injection once }(50 \mathrm{mg}) \text {, } \\
\text { or twice }(25 \mathrm{mg}) \text { a week }\end{array}$ & 3-6 days \\
\hline Adalimumab & TNF & Fully human IgGI MAb & Binding to TNF & $\begin{array}{l}\text { sc. injection } \\
\text { once every second week }\end{array}$ & 13 days \\
\hline Infliximab & TNF & $\begin{array}{l}\text { Chimeric murine-human } \lg \mathrm{GI} \\
\mathrm{MAb}\end{array}$ & $\begin{array}{l}\text { Binding to soluble and } \mathrm{mb} \\
\text { bound TNF }\end{array}$ & iv. infusion every $4-8$ weeks & 9 days \\
\hline Golimumab & TNF & Fully human IgGI MAb & $\begin{array}{l}\text { Binding to soluble and } \mathrm{mb} \\
\text { bound TNF }\end{array}$ & $\begin{array}{l}\text { sc. injection once a month or iv. } \\
\text { Infusion at } 0 \text { and } 4 \text { weeks, } \\
\text { thereafter every } 8 \text { weeks }\end{array}$ & 13 days \\
\hline $\begin{array}{l}\text { Certolizumab- } \\
\text { pegol }\end{array}$ & TNF & $\begin{array}{l}\text { Humanized pegylated anti-TNF } \\
\text { Fab' fragment }\end{array}$ & Binding to TNF & $\begin{array}{l}\text { sc. injection } \\
\text { once every second week }\end{array}$ & 14 days \\
\hline Anakinra & IL-I & $\begin{array}{l}\text { Recombinant human IL-I } \\
\text { receptor antagonist }\end{array}$ & $\begin{array}{l}\text { Binding to IL-I type-I } \\
\text { receptor }\end{array}$ & sc. injection once a day & $4-6$ hours \\
\hline Tocilizumab & IL-6 & $\begin{array}{l}\text { Humanized recombinant } \lg \mathrm{GI} \\
\mathrm{MAb}\end{array}$ & $\begin{array}{l}\text { Binding to soluble and mem- } \\
\text { brane bound IL- } 6 \text { receptor }\end{array}$ & iv. infusion every 4 weeks & $10-13$ days \\
\hline Rituximab & B cells & $\begin{array}{l}\text { Chimeric murine-human lgGI } \\
\text { MAb }\end{array}$ & $\begin{array}{l}\text { Binding to } C D 20 \text { and depletion } \\
\text { of } C D 20+B \text { cells }\end{array}$ & $\begin{array}{l}\text { Two initial infusions } 14 \text { days } \\
\text { apart. Courses may be repeated } \\
\text { every } 6 \text { months or more } \\
\text { frequently depending on } \\
\text { disease activity }\end{array}$ & $\begin{array}{l}\text { I8 days (range: } \\
5-76 \text { days) }\end{array}$ \\
\hline Abatacept & $\mathrm{T}$ cells & $\begin{array}{l}\text { Recombinant human fusion } \\
\text { protein of the extracellular } \\
\text { domain of CTLA-4 and the Fc } \\
\text { portion of lgGI }\end{array}$ & $\begin{array}{l}\text { Binding to CD80/ CD86, } \\
\text { blocking T-cell co-stimulation }\end{array}$ & $\begin{array}{l}\text { iv. infusion every } 4 \text { weeks or sc. } \\
\text { injection once a week }\end{array}$ & $\begin{array}{l}13 \text { days (range } \\
8-25 \text { days) }\end{array}$ \\
\hline
\end{tabular}

CTLA-4, cytotoxic T lymphocyte associated antigen 4; DMARDs, disease-modifying anti-rheumatic drugs; lgG, immunoglobulin G; IL, interleukin; iv, intravenous; MAb, monoclonal antibody; mb, membrane; sc, subcutaneous; TNF, tumor necrosis factor

* The half-lives provided here refer to the biological effect and the physical half-life reported by the manufacturers which may differ depending on the format of the drug.

a long-lasting low disease activity state on the combination of methotrexate plus etanercept, the latter drug can in many cases be continued at half the usual dose $[7,8]$ or at more sparse treatment intervals [9].

\section{Adalimumab}

Adalimumab is the first fully human monoclonal antibody binding TNF. It is administered subcutaneously and has a longer half-life than etanercept (approximately 13 days), allowing a less frequent injection interval (every second week). The clinical efficacy of adalimumab in combination with methotrexate was shown in patients with early aggressive rheumatoid arthritis [10] as well as in patients who had previously failed to respond to other biologic or non-biologic DMARDs [11,12]. A recent study evaluated the use of methotrexate + adalimumab as firstline treatment for patients with early rheumatoid arthritis, with a unique trial design that re-randomized patients who had achieved a low disease activity state with the combination after 24 weeks [13]. After 76 weeks, around $90 \%$ of patients who continued on both (versus around $80 \%$ of patients who continued with only methotrexate) had maintained low disease activity (disease activity score [DAS]28>3.2). While this difference was statistically significant, the most important conclusion might well be that, for at least a subset of patients with early rheumatoid arthritis, induction-maintenance is a highly successful therapeutic strategy with an obviously favorable healtheconomic profile.

\section{Infliximab}

Infliximab is a chimeric murine/human IgG1 monoclonal antibody, also directed against TNF (soluble and membrane bound), usually administered intravenously every 4-8 weeks. Ensuing randomized controlled trials showed that infliximab in combination with methotrexate produced a rapid reduction of signs and symptoms, reduced radiographically measured disease progression and improved physical function [14-16]. In addition, the reduced radiographic progression was shown to be independent of clinical response [14,17].

\section{Golimumab}

Golimumab is a human monoclonal antibody, binding to both soluble and membrane bound TNF. It has a halflife of approximately 13 days and is administered subcutaneously once a month. Recently, the Food and Drug Administration (FDA) approved an intravenous format of this drug for the treatment of rheumatoid arthritis, to be administered at 0 and 4 weeks, thereafter every 8 weeks. Golimumab has been shown to be effective in the treatment of moderate to severe rheumatoid 
arthritis patients who failed to respond or were naïve to methotrexate, as well as in patients who failed to respond to at least one anti-TNF therapy [18-20].

\section{Certolizumab pegol}

Certolizumab pegol is a pegylated, humanized anti-TNF Fab fragment. Since it lacks the Fc portion, it does not induce apoptosis through complement activation or antibody-dependent cell-mediated cytotoxicity (ADCC). The pegylation process (addition of polyethylene glycol) delays the elimination of this small antibody-derived protein, prolonging its half-life (approximately 14 days). Certolizumab is administered subcutaneously every second week. A study with a wider inclusion and fewer restrictions than most studies, named REALISTIC [21], confirmed the clinical benefit and overall safety and tolerability of this agent in a broad population of rheumatoid arthritis patients. Likewise, the CERTAIN trial [22] demonstrated that patients with moderately active rheumatoid arthritis may also benefit from this TNF-inhibitor.

\section{Anakinra}

Anakinra, a recombinant human IL-1 receptor antagonist, has a very short half-life (4-6 hours) and must be administered subcutaneously once a day. Due to this inconvenience, as well as indirect comparative reports showing limited success of anakinra in rheumatoid arthritis compared to TNF inhibitors [23-25], this drug is not commonly used in adult rheumatoid arthritis. Nevertheless, anakinra has been successfully used in juvenile rheumatoid arthritis and other autoinflammatory disorders [26-28].

\section{Tocilizumab}

Tocilizumab is a humanized recombinant IgG1 monoclonal antibody that binds to soluble and membrane bound IL-6 receptor. It has a half-life of 10-13 days and is administered intravenously every 4 weeks. A subcutaneous formulation of tocilizumab has been developed and was very recently approved in the United States. Tocilizumab (162 mg) injected subcutaneously once weekly has recently shown a comparable efficacy and safety profile to TCZ-IV ( $8 \mathrm{mg} / \mathrm{kg}$ ) [29,30]. Tocilizumab has proven effectiveness for the treatment of rheumatoid arthritis after inadequate response to conventional DMARDs [31] and also the treatment of rheumatoid arthritis refractory to anti-TNF therapy [32]. In the ADACTA trial [33], tocilizumab monotherapy was superior to adalimumab monotherapy.

\section{Cell-targeting agents (B and T lymphocytes) Rituximab}

Rituximab is a chimeric murine/human monoclonal antibody directed against CD20, an antigen expressed by
B cells at different stages of differentiation (pre-B cell to mature stages) but not by haematopoietic stem cells or plasma cells. It induces the depletion of B cells, which are involved in the production of autoantibodies as well as in the induction of $\mathrm{T}$ cell activation and production of pro-inflammatory cytokines [34]. This biologic was approved originally for the treatment of non-Hodgkin lymphoma and then approved in 2006 as a second-line therapy (after failure of anti-TNF therapy) in patients with moderate to severe rheumatoid arthritis. Its efficacy has been shown in patients who failed to respond to methotrexate or to one or more anti-TNF therapies [35,36] after a single course of two infusions of rituximab. One study in rheumatoid arthritis patients (with inadequate response to a previous anti-TNF agent) suggested a relative benefit of rituximab over alternative anti-TNF agents on disease activity, but found a similar rate of radiographic erosion progression between the two treatments [37]. In addition, the presence of autoantibodies appears to favor clinical responses to rituximab, as indicated by studies showing a better effect among seropositive rheumatoid arthritis patients compared to seronegative rheumatoid arthritis patients [38-40]. The effectiveness of rituximab was also reported in a refractory group of rheumatoid arthritis patients with long disease duration. Moreover, it appeared to be relatively safe in a population with high prevalence of comorbidities, including malignancy and recurrent infections [41].

\section{Abatacept}

Abatacept has been approved for the treatment of patients with moderate to severe rheumatoid arthritis who have had an inadequate response to one or more conventional or biologic DMARDs. It is a fully human fusion protein comprising the extracellular domain of cytotoxic $\mathrm{T}$ lymphocyte associated antigen-4 (CTLA-4) linked to the Fc portion of human IgG.

The antigen-specific interaction between antigen presenting cells (APCs) and T cells is normally accompanied by the binding of a ligand on the APC (CD80 or CD86) to the co-stimulatory receptor on T cells (CD28). This interaction is called co-stimulation and results in an effective $\mathrm{T}$ cell activation characterized by proliferation and production of inflammatory cytokines (IL-2, TNF). The inhibitory antigen CTLA-4 binds also to CD80 and CD86, though with a higher affinity than CD28 and with an inhibitory effect. Abatacept prevents T cell co-stimulation by binding, with its CTLA-4 portion, to CD80 and CD86, blocking in this way CD28-mediated T cell activation.

Abatacept is administered in infusions (once every 4 weeks) or subcutaneously (once every week). Both treatment options showed comparable efficacy and safety in patients 
with inadequate response to methotrexate [42]. A recent head-to-head trial comparing abatacept and adalimumab (both combined with methotrexate) displayed nearly identical efficacy, with some safety outcomes favoring abatacept $[43,44]$.

\section{Inhibitor of intracellular signaling pathways Tofacitinib}

Tofacitinib, a new non-biologic agent, is the first Janus kinase (JAK) inhibitor approved by the FDA as well as regulatory agencies in various other countries (Japan, Switzerland, Russia, Argentina, Kuwait and The United Arab Emirates) for the treatment of rheumatoid arthritis. In contrast, the European Medicines Agency did not approve this drug. JAK enzymes are a group of four cytoplasmic tyrosine kinases: JAK1, JAK2, JAK3 and TYK. These enzymes bind to the intracellular portion of various cytokine receptors and, upon stimulation of the tyrosine kinase-associated receptor, they transmit the signal from the cell surface into the nucleus by phosphorylation and activation of signal transducer and activator of transcription (STAT) molecules. JAKs are involved in the differentiation and activation of lymphocytes as well as in the secretion of proinflammatory cytokines. A number of cytokines known to be relevant in rheumatoid arthritis pathophysiology (such as IL-2, IL-4, IL-6, IL-7, IL-9, IL-15 and IL-21) are regulated by JAK-dependent pathways. Tofacitinib is an inhibitor of Janus kinase 1 and 3 (with much lower affinity for JAK2 and TYK) [45]. Tofacitinib is administered orally and the recommended dose is $5 \mathrm{mg}$ twice daily. It can be used as monotherapy or in combination with methotrexate or other sDMARDs (synthetic DMARDs - sulfasalazine, leflunomide or hydroxychloroquine) to treat moderately to severely active rheumatoid arthritis in patients who have had an inadequate response to methotrexate. The clinical efficacy of tofacitinib was shown to be very similar to the antiTNF agent adalimumab [46].

\section{Major safety issues with biological and targeted synthetic DMARDs}

Safety concerns common to all anti-rheumatic therapies include an increased risk for viral and bacterial infections [47]. Patients on anti-TNFs have a higher risk of tuberculosis (TB) reactivation and therefore TB screening before treatment initiation is compulsory. Anti-TNF treatment has also been associated with an increased risk of herpes zoster. Infliximab was associated with a significantly higher risk of patient withdrawals due to adverse events compared to controls and to other antiTNFs. Anti-TNFs do not appear to increase the risk of malignancies in general; earlier reports of an increased risk of lymphoma or non-melanoma skin cancer were not confirmed in later and larger studies [48,49]. A recent study from the Swedish registry showed a slightly increased risk of melanoma in rheumatoid arthritis patients treated with anti-TNF agents [50].

SWITCH-RA, a prospective observational study, showed an overall similar incidence of adverse events in patients, non-responsive or intolerant to a single anti-TNF agent, who switched to rituximab or to a second anti-TNF [51]. However, reports suggested an increased risk (1 case per 25,000 individuals) of progressive multifocal leukoencephalopathy due to reactivation of John Cunningham (JC) virus in rheumatoid arthritis patients treated with rituximab [52,53]. Although this is a rare adverse event associated with rituximab therapy in rheumatoid arthritis patients, the devastating nature of progressive multifocal leukoencephalopathy advocates for sustained vigilance in this group of patients.

According to data from randomized controlled trials and observational studies, the main safety risk for patients receiving abatacept is infection [54]. A head-to-head comparison of abatacept versus adalimumab showed similar safety profiles and fewer injection site reactions with abatacept [55].

Tocilizumab has a distinct safety profile. Although clinical events (including infections and malignancies) occur at comparable rates to anti-TNF agents, there are more instances of abnormal laboratory tests on follow-up, including elevated liver enzymes, cytopenias, and lipid elevations. In addition, inhibition of IL- 6 by tocilizumab prevents the production of C-reactive protein (CRP) in response to inflammation. A few case reports of tocilizumabtreated patients with moderate to severe bacterial infections, and normal CRP support the idea that CRP may not be used as a marker in case of infection [56-58]. Reports on the incidences of herpes zoster (multidermatomal or ophthalmic) with tocilizumab $[59,60]$ indicate an increased risk for this serious infection in tocilizumabtreated patients. If this risk were confirmed, systematic vaccination against varicella-zoster virus or antiviral longterm prophylaxis may be considered.

Overall safety of tofacitinib in the clinical trials was acceptable, with infection rates similar to biologics [61]. A number of laboratory abnormalities and an increased incidence of infections (including herpes zoster) were seen, not unlike those described above with the anti-IL6 agent tocilizumab and, indeed, IL- 6 signaling is dependent on JAK1 and 2 [62]. The ORAL Standard trial, a phase 3 study, compared the efficacy and safety of tofacitinib and of the anti-TNF agent adalimumab to placebo, showing similar efficacy for the active compounds versus placebo, 
with an increased rate of serious infections in the tofacitinib group [46]. Larger trials of longer duration are necessary to assess the risk of infections and other adverse events associated with tofacitinib and to compare the safety of this drug with that of the other available treatments for rheumatoid arthritis.

\section{Biosimilar agents}

The patents for many biological agents are going to expire in the coming years, and this has triggered major interest in the development of "biosimilars" by several companies. The advent of these potentially less expensive alternatives could make the treatment of rheumatoid arthritis more cost-effective, and might afford access to biologics to a greater number of rheumatoid arthritis patients worldwide. However, biosimilars cannot be identical to the original biologics, due in part to stochastic variability in posttranslational modifications to the molecules, and in part to potential differences in the manufacturing conditions. These differences have raised some concerns regarding the efficacy, immunogenicity and safety profile of the intended copies. As a consequence, the registration and approval process for biosimilars is considerably more demanding than for pharmaceutical generics (but less so than for completely new drugs). As the production costs for biosimilars will not be different from biologics, they will still remain costly, and the savings compared to original biologics may be relatively modest. The status of development as well as regulatory issues related to the approval of biosimilar agents in the world has been reviewed in a recent publication by Scheinberg and Kay [63].

\section{New anti-rheumatic agents in the pipeline}

Emerging cytokine-targeting therapies include anti-IL-17 and anti-IL-15. Serum IL-17A levels and, to a greater extent, synovial fluid IL-17A levels are elevated in many patients with rheumatoid arthritis, which is associated with cartilage and bone degradation. The anti-IL-17A monoclonal antibodies secukinumab and ixekizumab, and the anti-IL-17 receptor subunit A monoclonal antibody brodalumab have been evaluated in phase II clinical trials. Of these, secukinumab is the furthest advanced, with phase III trials ongoing in patients who had inadequate response to a previous TNF-blocker therapy [64]. Clinical benefit in disease activity was also observed in a phase I/II trial where patients with active rheumatoid arthritis received anti-IL-15 as monotherapy [65]. Another cytokine that has been found to play a role in the pathogenesis of rheumatoid arthritis is IL-20. This cytokine is increased in the sinovium of patients with rheumatoid arthritis. NNC0109-0012, a human recombinant IgG4 that binds and neutralizes IL-20, is now in phase II trials. A doubleblind study has shown promising results, with clear improvements of disease activity scores, physical function and pain, particularly in seropositive rheumatoid arthritis patients [66].

Among cell-receptor targeting therapies, there have recently been studies of the non-depleting antibody BT-061 (tregalizumab) that is thought to act by activating $\mathrm{T}$ regulatory cells, which have been found to malfunction in autoimmune diseases such as psoriasis and rheumatoid arthritis. Since only natural regulatory mechanisms would be activated by BT-061, it is expected that it would be safer than other available therapies as the immune system remains mainly functional to fight infections. The TREAT $2 \mathrm{~b}$ is a phase IIb study investigating the safety and efficacy of tregalizumab in combination with methotrexate in the treatment of subjects with active rheumatoid arthritis who have had an inadequate response to methotrexate $[67,68]$.

Due to the success of JAK inhibition, several JAK inhibitors are currently being tested at different stages of development, including baricitinib, a JAK1/2 inhibitor $[69,70]$, and VX-509, a JAK3 inhibitor [71], which produce a clinical improvement superior to placebo.

Other intracellular molecules that were considered suitable therapeutic targets due to their role in the transduction of inflammatory signals, including the spleen tyrosine kinase (SYK) and the mitogen-activated protein (MAP) p38 kinases, led to the development of new classes of drugs evaluated in rheumatoid arthritis clinical trials that were subsequently abandoned due to lack of efficacy [72].

\section{Conclusions and future perspectives}

The discovery and targeting of new relevant pathways in the pathogenesis of rheumatoid arthritis have provided a greater possibility of controlling this disease, although more knowledge is required in order to better allocate suitable therapy to our patients. It is widely accepted that the initiation of biologic treatment should be reserved for patients who have failed to respond to at least one DMARD, most often methotrexate. Yet, greater efforts should be put into the optimization of the usage of the existing drugs.

It is known that the main advantage of biologics when compared to DMARDs is a more rapid effect, as well as prevention of radiographic progression. Given the benefits of aggressive and early treatment in the long run, there is consequently a lot of interest at the moment in finding out whether such early aggressive treatment should include biologics.

At present, the limited data that are available from headto-head clinical trials do not strongly support the use of one agent over another. At this time, we are participating 
in a large Nordic investigator-initiated clinical trial, NORDSTAR, where initial conventional therapy is compared directly to anti-TNF with certolizumab, abatacept, or anti-IL6.

The ultimate goal in rheumatoid arthritis is to achieve remission, which could be accomplished through a personalized treatment that provides the right drug at the right dose for the adequate length of time, improving outcomes and minimizing side effects.

Clinicians still lack reliable tools to predict which patients are more likely to respond to a given biologic. In this respect, biomarkers are promising tools. The availability of biomarker scores offers the possibility of improving the clinical assessment of disease activity as a decision-helping tool in rheumatoid arthritis management $[73,74]$.

It would be advantageous to be able to predict not only whether patients will respond to a given biologic but also whether continuation will be needed once treatment target has been achieved. Therefore, studies dealing with tapering or stopping therapy as well as predictors of response to therapy are of enormous relevance in the future.

In summary, the development of biologic therapies has greatly advanced the field of rheumatoid arthritis therapeutics; trials of additional biologics, the burgeoning development of small molecular compounds with comparable efficacy, and the optimization of therapeutic strategies using all available classes of agents will lead to ever more impressive improvements in the results achieved for our patients.

\section{Abbreviations}

APC, antigen presenting cell; CRP, C-reactive protein; CTLA-4, cytotoxic T lymphocyte associated antigen-4; DMARD, disease-modifying anti-rheumatic drug; FDA, Food and Drug Administration; IgG, immunoglobulin G; IL, interleukin; JAK, Janus kinase; TNF, tumor necrosis factor; TB, tuberculosis.

\section{Disclosures}

Ronald van Vollenhoven has received research support and/or honoraria from AbbVie, Biotest, BMS, GSK, Lilly, Merck, Pfizer, Roche, UCB and Vertex.

\section{References}

I. Alamanos $\mathrm{Y}$, Drosos AA: Epidemiology of adult rheumatoid arthritis. Autoimmun Rev 2005, 4:130-36.

2. Aletaha D, Neogi T, Silman AJ, Funovits J, Felson DT, Bingham CO 3rd, Birnbaum NS, Burmester GR, Bykerk VP, Cohen MD, Combe B, Costenbader KH, Dougados M, Emery P, Ferraccioli G, Hazes JM, Hobbs K, Huizinga TW, Kavanaugh A, Kay J,
Kvien TK, Laing T, Mease P, Ménard HA, Moreland LW, Naden RL, Pincus T, Smolen JS, Stanislawska-Biernat E, Symmons D, Tak PP, Upchurch KS, Vencovsky J, Wolfe F, Hawker G: 2010 rheumatoid arthritis classification criteria: an American College of Rheumatology/European League Against Rheumatism collaborative initiative. Ann Rheum Dis 2010, 69:1580-88.

3. Singh JA, Furst DE, Bharat A, Curtis JR, Kavanaugh AF, Kremer JM, Moreland LW, O'Dell J, Winthrop KL, Beukelman T, Bridges SLJr, Chatham WW, Paulus HE, Suarez-Almazor M, Bombardier C, Dougados M, Khanna D, King CM, Leong AL, Matteson EL, Schousboe JT, Moynihan E, Kolba KS, Jain A, Volkmann ER, Agrawal H, Bae S, Mudano AS, Patkar NM, Saag KG: 2012 update of the 2008 American College of Rheumatology recommendations for the use of disease-modifying antirheumatic drugs and biologic agents in the treatment of rheumatoid arthritis. Arthritis Care Res 2012, 64:625-39.

4. Genovese MC, Bathon JM, Martin RW, Fleischmann RM, Tesser JR, Schiff MH, Keystone EC, Wasko MC, Moreland LW, Weaver AL, Markenson J, Cannon GW, Spencer-Green G, Finck BK: Etanercept versus methotrexate in patients with early rheumatoid arthritis: two-year radiographic and clinical outcomes. Arthritis Rheum 2002, 46: I443-50.

5. Emery P, Breedveld FC, Hall S, Durez P, Chang DJ, Robertson D, Singh A, Pedersen RD, Koenig AS, Freundlich B: Comparison of methotrexate monotherapy with a combination of methotrexate and etanercept in active, early, moderate to severe rheumatoid arthritis (COMET): a randomised, double-blind, parallel treatment trial. Lancet 2008, 372:375-82.

\section{FlOOOPrime \\ RECOMMENDED}

6. van der Heijde D, Klareskog L, Rodriguez-Valverde V, Codreanu C, Bolosiu H, Melo-Gomes J, Tornero-Molina J, Wajdula J, Pedersen R, Fatenejad S; TEMPO Study Investigators: Comparison of etanercept and methotrexate, alone and combined, in the treatment of rheumatoid arthritis: two-year clinical and radiographic results from the TEMPO study, a double-blind, randomized trial. Arthritis Rheum 2006, 54:1063-74.

\section{FlOOOPrime}

\section{RECOMMENDED}

7. Van Vollenhoven RF, Østergaard M, Leirisalo-Repo M, Uhlig T, Jansson M, Klackenberg $\AA$, K. H: In Rheumatoid Arthritis Patients With Stable Low Disease Activity On Methotrexate Plus Etanercept, Continuation Of Etanercept $50 \mathrm{mg}$ Weekly or 25 mg Weekly are Both Clinically Superior to Discontinuation: Results From a Randomized, 3-Armed, Double-Blind Clinical Trial. The DOSERA study. In: EULAR Cogress 20 I3; Madrid, Spain; 2013.

8. Smolen JS, Nash P, Durez P, Hall S, Ilivanova E, Irazoque-Palazuelos F, Miranda P, Park MC, Pavelka K, Pedersen R, Szumski A, Hammond C, Koenig AS, Vlahos B: Maintenance, reduction, or withdrawal of etanercept after treatment with etanercept and methotrexate in patients with moderate rheumatoid arthritis (PRESERVE): a randomised controlled trial. Lancet 2013, 381:918-29.

\section{FlOOOPrime}

RECOMMENDED

9. Fautrel B, Pham T, Morel J, Alfaiate T, Dernis E, Gaudin P, Mariette X, F. T: Impact of Progressive Spacing of TNF-blocker Injections on Signs and Symptoms of Rheumatoid Arthritis Patients in DAS28 Remission: The STRASS Ramdomized Controled Trial. In: EULAR Congress: 2013; Madrid, Spain; 2013.

10. Breedveld FC, Weisman MH, Kavanaugh AF, Cohen SB, Pavelka K, van Vollenhoven R, Sharp J, Perez JL, Spencer-Green GT: The PREMIER study: A multicenter, randomized, double-blind clinical trial of combination therapy with adalimumab plus methotrexate versus methotrexate alone or adalimumab alone in patients with early, aggressive rheumatoid arthritis who had not had 
previous methotrexate treatment. Arthritis Rheum 2006, 54:26-37.

\section{FIOOOPrime
RECOMMENDED}

II. Burmester GR, Mariette X, Montecucco C, Monteagudo-Saez I, Malaise M, Tzioufas AG, Bijlsma JW, Unnebrink K, Kary S, Kupper $\mathrm{H}$ : Adalimumab alone and in combination with disease-modifying antirheumatic drugs for the treatment of rheumatoid arthritis in clinical practice: the Research in Active Rheumatoid Arthritis (ReAct) trial. Ann Rheum Dis 2007, 66:732-39.

12. Bombardieri S, Ruiz AA, Fardellone $P$, Geusens $P$, McKenna $F$, Unnebrink K, Oezer U, Kary S, Kupper H, Burmester GR; Research in Active Rheumatoid Arthritis (ReAct) Study Group: Effectiveness of adalimumab for rheumatoid arthritis in patients with a history of TNF-antagonist therapy in clinical practice. Rheumatology 2007, 46:1191-99.

13. Smolen JS, Emery P, Fleischmann R, van Vollenhoven RF, Pavelka K, Durez P, Guérette B, Kupper H, Redden L, Arora V, Kavanaugh A: Adjustment of therapy in rheumatoid arthritis on the basis of achievement of stable low disease activity with adalimumab plus methotrexate or methotrexate alone: the randomised controlled OPTIMA trial. Lancet 2014, 383:321-32.

14. Lipsky PE, van der Heijde DM, St Clair EW, Furst DE, Breedveld FC, Kalden JR, Smolen JS, Weisman M, Emery P, Feldmann M, Harriman GR, Maini RN; Anti-Tumor Necrosis Factor Trial in Rheumatoid Arthritis with Concomitant Therapy Study Group: Infliximab and methotrexate in the treatment of rheumatoid arthritis. Anti-Tumor Necrosis Factor Trial in Rheumatoid Arthritis with Concomitant Therapy Study Group. N Engl J Med 2000, 343:1594-602

\section{FlOOOPrime
RECOMMENDED}

15. St Clair EW, van der Heijde DM, Smolen JS, Maini RN, Bathon JM, Emery P, Keystone E, Schiff M, Kalden JR, Wang B, Dewoody K, Weiss R, Baker D; Active-Controlled Study of Patients Receiving Infliximab for the Treatment of Rheumatoid Arthritis of Early Onset Study Group: Combination of infliximab and methotrexate therapy for early rheumatoid arthritis: a randomized, controlled trial. Arthritis Rheum 2004, 50:3432-43.

\section{FlOOOPrime} RECOMMENDED

16. Westhovens R, Yocum D, Han J, Berman A, Strusberg I, Geusens P, Rahman MU, Group SS: The safety of infliximab, combined with background treatments, among patients with rheumatoid arthritis and various comorbidities: a large, randomized, placebo-controlled trial. Arthritis Rheum 2006, 54:1075-86.

\section{FlOOOPrime}

\section{RECOMMENDED}

17. Smolen JS, Han C, Bala M, Maini RN, Kalden JR, van der Heijde D, Breedveld FC, Furst DE, Lipsky PE, Group AS: Evidence of radiographic benefit of treatment with infliximab plus methotrexate in rheumatoid arthritis patients who had no clinical improvement: a detailed subanalysis of data from the anti-tumor necrosis factor trial in rheumatoid arthritis with concomitant therapy study. Arthritis Rheum 2005, 52:1020-30.

18. Keystone EC, Genovese MC, Klareskog L, Hsia EC, Hall ST, Miranda PC, Pazdur J, Bae SC, Palmer W, Zrubek J, Wiekowski M, Visvanathan S, Wu Z, Rahman MU; GO-FORWARD Study: Golimumab, a human antibody to tumour necrosis factor \{alpha\} given by monthly subcutaneous injections, in active rheumatoid arthritis despite methotrexate therapy: the GO-FORWARD Study. Ann Rheum Dis 2009, 68:789-96.

\section{FlOOOPrime}

19. Smolen JS, Kay J, Doyle MK, Landewé R, Matteson EL, Wollenhaupt J, Gaylis N, Murphy FT, Neal JS, Zhou Y, Visvanathan S, Hsia EC, Rahman MU; GO-AFTER study investigators: Golimumab in patients with active rheumatoid arthritis after treatment with tumour necrosis factor alpha inhibitors (GO-AFTER study): a multicentre, randomised, double-blind, placebocontrolled, phase III trial. Lancet 2009, 374:210-2I.

\section{FlOOOPrime}

\section{RECOMMENDED}

20. Emery P, Fleischmann RM, Moreland LW, Hsia EC, Strusberg I, Durez P, Nash P, Amante EJ, Churchill M, Park W, Pons-Estel BA, Doyle MK, Visvanathan S, Xu W, Rahman MU: Golimumab, a human antitumor necrosis factor alpha monoclonal antibody, injected subcutaneously every four weeks in methotrexate-naive patients with active rheumatoid arthritis: twenty-four-week results of a phase III, multicenter, randomized, double-blind, placebo-controlled study of golimumab before methotrexate as first-line therapy for early-onset rheumatoid arthritis. Arthritis Rheum 2009, 60:2272-83.

\section{FlOOOPrime
RECOMMENDED}

21. Weinblatt ME, Fleischmann R, Huizinga TW, Emery P, Pope J, Massarotti EM, van Vollenhoven RF, Wollenhaupt J, Bingham CO 3rd, Duncan B, Goel N, Davies OR, Dougados M: Efficacy and safety of certolizumab pegol in a broad population of patients with active rheumatoid arthritis: results from the REALISTIC phase IIIb study. Rheumatology 20I2, 5 I:2204-I4.

22. Smolen J, Emery P, Ferraccioli G, Samborski W, Berenbaum F, Davies O Koetse W, Bennett B, Burkhardt H: Maintenance of Remission in Rheumatoid Arthritis Patients with Low-moderate Disease Activity Following Withdrawal of Certolizumab-pegol Treatment: Week 52 Results From The CERTAIN Study. In: ACR Annual Meeting: 2012; Washington D.C., USA; 2012.

23. Singh JA, Christensen R, Wells GA, Suarez-Almazor ME, Buchbinder R, Lopez-Olivo MA, Ghogomu ET, Tugwell P: A network meta-analysis of randomized controlled trials of biologics for rheumatoid arthritis: a Cochrane overview. CMAJ 2009, | 81 1:787-96.

24. O'Dell JR: Therapeutic strategies for rheumatoid arthritis. $N$ Engl J Med 2004, 350:2591-602.

25. Turkstra E, Ng SK, Scuffham PA: A mixed treatment comparison of the short-term efficacy of biologic disease modifying antirheumatic drugs in established rheumatoid arthritis. Curr Med Res Opin 2011, 27:1885-97.

26. Sandborg C, Mellins ED: A new era in the treatment of systemic juvenile idiopathic arthritis. N Engl J Med 20I2, 367:2439-40.

27. Giampietro C, Fautrel B: Anti-Interleukin-I Agents in Adult Onset Still's Disease. Int J Inflam 2012, 2012:317820.

28. McGonagle D, Tan AL, Madden J, Emery P, McDermott MF: Successful treatment of resistant pseudogout with anakinra. Arthritis Rheum 2008, 58:631-33.

29. Burmester GR, Rubbert-Roth A, Cantagrel A, Hall S, Leszczynski P, Feldman D, Rangaraj MJ, Roane G, Ludivico C, Lu P, Rowell L, Bao M, Mysler EF: A randomised, double-blind, parallel-group study of the safety and efficacy of subcutaneous tocilizumab versus intravenous tocilizumab in combination with traditional disease-modifying antirheumatic drugs in patients with moderate to severe rheumatoid arthritis (SUMMACTA study). Ann Rheum Dis 2013.

30. Ogata A, Tanimura $K$, Sugimoto $T$, Inoue $H$, Urata $Y$, Matsubara $T$, Kondo M, Ueki Y, Iwahashi M, Tohma S, Ohta S, Saeki Y, Tanaka T; Musashi Study Investigators: A phase 3 study of the efficacy and safety of subcutaneous versus intravenous tocilizumab monotherapy in patients with rheumatoid arthritis (MUSASHI). Arthritis Care Res 2014, 66:344-54.

31. Genovese MC, McKay JD, Nasonov EL, Mysler EF, da Silva NA, Alecock E, Woodworth T, Gomez-Reino Jj: Interleukin-6 receptor inhibition with tocilizumab reduces disease activity in rheumatoid arthritis with inadequate response to disease-modifying antirheumatic drugs: the tocilizumab in combination with 
traditional disease-modifying antirheumatic drug therapy study. Arthritis Rheum 2008, 58:2968-80.

\section{FIOOOPrime}

32. Emery P, Keystone E, Tony HP, Cantagrel A, van Vollenhoven R, Sanchez A, Alecock E, Lee J, Kremer J: IL-6 receptor inhibition with tocilizumab improves treatment outcomes in patients with rheumatoid arthritis refractory to anti-tumour necrosis factor biologicals: results from a 24-week multicentre randomised placebo-controlled trial. Ann Rheum Dis 2008, 67:1516-23.

33. Gabay C, Emery P, van Vollenhoven R, Dikranian A, Alten R, Pavelka K, Klearman M, Musselman D, Agarwal S, Green J, Kavanaugh A; ADACTA Study Investigators: Tocilizumab monotherapy versus adalimumab monotherapy for treatment of rheumatoid arthritis (ADACTA): a randomised, double-blind, controlled phase 4 trial. Lancet 2013, 38I: I54I-50.

34. Dorner T, Burmester GR: The role of B cells in rheumatoid arthritis: mechanisms and therapeutic targets. Curr Opin Rheumatol 2003, 15:246-52.

35. Edwards JC, Szczepanski L, Szechinski J, Filipowicz-Sosnowska A, Emery P, Close DR, Stevens RM, Shaw T: Efficacy of B-celltargeted therapy with rituximab in patients with rheumatoid arthritis. N Engl J Med 2004, 350:2572-8I.

\section{FlOOOPrime RECOMMENDED}

36. Cohen SB, Emery P, Greenwald MW, Dougados M, Furie RA, Genovese MC, Keystone EC, Loveless JE, Burmester GR, Cravets MW, Hessey EW, Shaw T, Totoritis MC; REFLEX Trial Group: Rituximab for rheumatoid arthritis refractory to antitumor necrosis factor therapy: Results of a multicenter, randomized, double-blind, placebo-controlled, phase III trial evaluating primary efficacy and safety at twenty-four weeks. Arthritis Rheum 2006, 54:2793-806.

\section{FlOOOPRime
RECOMMENDED}

37. Finckh A, Moller B, Dudler J, Walker UA, Kyburz D, Gabay C; physicians of the Swiss Clinical Quality Management for Rheumatoid $A$, physicians of S-R: Evolution of radiographic joint damage in rituximab-treated versus TNF-treated rheumatoid arthritis cases with inadequate response to TNF antagonists. Ann Rheum Dis 2012, 71:1680-5.

38. Chatzidionysiou K, Lie E, Nasonov E, Lukina G, Hetland ML, Tarp U, Gabay C, van Riel PL, Nordström DC, Gomez-Reino J, Pavelka K, Tomsic M, Kvien TK, van Vollenhoven RF: Highest clinical effectiveness of rituximab in autoantibody-positive patients with rheumatoid arthritis and in those for whom no more than one previous TNF antagonist has failed: pooled data from 10 European registries. Ann Rheum Dis 2011, 70:1575-80.

39. Lal P, Su Z, Holweg CT, Silverman GJ, Schwartzman S, Kelman A, Read S, Spaniolo G, Monroe JG, Behrens TW, Townsend MJ: Inflammation and autoantibody markers identify rheumatoid arthritis patients with enhanced clinical benefit following rituximab treatment. Arthritis Rheum 2011, 63:368I-91.

\section{FIOOOPrime}

40. Quartuccio L, Fabris M, Salvin S, Atzeni F, Saracco M, Benucci M, Cimmino M, Morassi P, Masolini P, Pellerito R, Cutolo M, Puttini PS, De Vita S: Rheumatoid factor positivity rather than anti-CCP positivity, a lower disability and a lower number of anti-TNF agents failed are associated with response to rituximab in rheumatoid arthritis. Rheumatology 2009, 48:1557-9.

\section{FlOOOPrime}

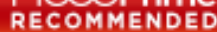

4I. Nicholls D, Zochling J, Boers A, Champion G, Mathers D, Riordan J, Youssef $\mathrm{P}, \mathrm{Scott}$ ], Griffiths $\mathrm{H}$ : A retrospective chart review of the use of rituximab for the treatment of rheumatoid arthritis in Australian rheumatology practice. Int J Rheum Dis 2013.

\section{FlOOOPrime}

RECOMMENDED

42. Genovese MC, Covarrubias A, Leon G, Mysler E, Keiserman M, Valente R, Nash P, Simon-Campos JA, Porawska W, Box J, Legerton C 3rd, Nasonov E, Durez P, Aranda R, Pappu R, Delaet I, Teng J, Alten R: Subcutaneous abatacept versus intravenous abatacept: a phase IIIb noninferiority study in patients with an inadequate response to methotrexate. Arthritis Rheum 20I I, 63:2854-64.

43. Schiff $M$, Weinblatt ME, Valente R, van der Heijde D, Citera G, Elegbe A, Maldonado M, Fleischmann R: Head-to-head comparison of subcutaneous abatacept versus adalimumab for rheumatoid arthritis: two-year efficacy and safety findings from AMPLE trial. Ann Rheum Dis 2014, 73:86-94.

\section{FlOOOPrime \\ RECOMMENDED}

44. Weinblatt ME, Schiff M, Valente R, van der Heijde D, Citera G, Zhao C, Maldonado M, Fleischmann R: Head-to-head comparison of subcutaneous abatacept versus adalimumab for rheumatoid arthritis: findings of a phase IIIb, multinational, prospective, randomized study. Arthritis Rheum 2013, 65:28-38.

\section{FlOOOPrime
RECOMMENDED}

45. Cutolo M: The kinase inhibitor tofacitinib in patients with rheumatoid arthritis: latest findings and clinical potential. Ther Adv Musculoskelet Dis 2013, 5:3-I I.

46. van Vollenhoven RF, Fleischmann R, Cohen S, Lee EB, García Meijide JA, Wagner S, Forejtova S, Zwillich SH, Gruben D, Koncz T, Wallenstein GV, Krishnaswami S, Bradley JD, Wilkinson B; ORAL Standard Investigators: Tofacitinib or adalimumab versus placebo in rheumatoid arthritis. N Engl J Med 20I2, 367:508-19.

\section{FlOOOPrime} RECOMMENDED

47. Ramiro S, Gaujoux-Viala C, Nam JL, Smolen JS, Buch M, Gossec L, van der Heijde D, Winthrop K, Landewe R: Safety of synthetic and biological DMARDs: a systematic literature review informing the 2013 update of the EULAR recommendations for management of rheumatoid arthritis. Ann Rheum Dis 2014, 73:529-35.

48. Askling J, van Vollenhoven RF, Granath F, Raaschou P, Fored CM, Baecklund E, Dackhammar C, Feltelius N, Cöster L, Geborek P, Jacobsson LT, Lindblad S, Rantapää-Dahlqvist S, Saxne T, Klareskog L: Cancer risk in patients with rheumatoid arthritis treated with anti-tumor necrosis factor alpha therapies: does the risk change with the time since start of treatment? Arthritis Rheum 2009, 60:3180-89.

FlOOOPrime

49. Carmona L, Abasolo L, Descalzo MA, Perez-Zafrilla B, Sellas A, de Abajo F, Gomez-Reino J], Group BS, Group ES: Cancer in patients with rheumatic diseases exposed to TNF antagonists. Semin Arthritis Rheum 201I, 4I:7I-80.

50. Raaschou P, Simard JF, Holmqvist M, Askling J, Group AS: Rheumatoid arthritis, anti-tumour necrosis factor therapy, and risk of malignant melanoma: nationwide population based prospective cohort study from Sweden. BMJ 20I3, 346:f 1939 .

\section{FlOOOPrime} RECOMMENDED

5I. Emery P, Gottenberg JE, Rubbert-Roth A, Sarzi-Puttini P, Choquette D, Martínez Taboada VM, Barile-Fabris L, Moots RJ, Ostor A, Andrianakos A, Gemmen E, Mpofu C, Chung C, Gylvin LH, Finckh A: Rituximab versus an alternative TNF inhibitor in patients with rheumatoid arthritis who failed to respond to a single previous TNF inhibitor: SWITCH-RA, a global, 
observational, comparative effectiveness study. Ann Rheum Dis 2014.

\section{FlOOOPrime}

52. Clifford DB, Ances B, Costello C, Rosen-Schmidt S, Andersson M, Parks D, Perry A, Yerra R, Schmidt R, Alvarez E, Tyler KL: Rituximab-associated progressive multifocal leukoencephalopathy in rheumatoid arthritis. Arch Neurol 20I I, 68: I I56-64.

\section{FlOOPrime}

\section{RECOMMENDED}

53. Molloy ES, Calabrese LH: Progressive multifocal leukoencephalopathy associated with immunosuppressive therapy in rheumatic diseases: evolving role of biologic therapies. Arthritis Rheum 2012, 64:3043-5I.

\section{FIOOOPrime
RECOMMENDED}

54. Atzeni F, Sarzi-Puttini P, Mutti A, Bugatti S, Cavagna L, Caporali R: Long-term safety of abatacept in patients with rheumatoid arthritis. Autoimmun Rev 2013, I 2: I I I5-7.

55. Schiff M, Weinblatt ME, Valente R, van der Heijde D, Citera G, Elegbe A, Maldonado M, Fleischmann R: Head-to-head comparison of subcutaneous abatacept versus adalimumab for rheumatoid arthritis: two-year efficacy and safety findings from AMPLE trial. Ann Rheum Dis 2014, 73:86-94.

56. Hirao M, Nampei A, Shi K, Yoshikawa H, Nishimoto N, Hashimoto J: Diagnostic features of mild cellulitis phlegmon in patients with rheumatoid arthritis treated with tocilizumab: a report of two cases. Mod Rheumatol 201 I, 2 1:673-7.

57. Bari SF, Khan $\mathrm{A}$, Lawson $\mathrm{T}$ : $\mathrm{C}$ reactive protein may not be reliable as a marker of severe bacterial infection in patients receiving tocilizumab. $B M J$ case reports $2013,2013$.

58. Fujiwara H, Nishimoto N, Hamano Y, Asanuma N, Miki S, Kasayama S, Suemura M: Masked early symptoms of pneumonia in patients with rheumatoid arthritis during tocilizumab treatment: a report of two cases. Mod Rheumatol 2009, 19:64-8.

59. Nishimoto N, Miyasaka N, Yamamoto K, Kawai S, Takeuchi T, Azuma J: Long-term safety and efficacy of tocilizumab, an anti-IL-6 receptor monoclonal antibody, in monotherapy, in patients with rheumatoid arthritis (the STREAM study): evidence of safety and efficacy in a 5-year extension study. Ann Rheum Dis 2009, 68: 1580-4.

\section{FlOOOPrime} RECOMMENDED

60. Roux C, Breuil V, Albert C, Allam V, Grisot C, Chami H, Dasilva V, Euller-Ziegler L: Ophthalmic herpes zoster infection in patients with rheumatoid arthritis who were treated with tocilizumab. J Rheumatol 201 I, 38:399.

6I. Rakieh C, Conaghan PG: Tofacitinib for treatment of rheumatoid arthritis. Adv Ther 2013, 30:713-26.

62. Kontzias A, Kotlyar A, Laurence A, Changelian P, O'Shea J]: Jakinibs: a new class of kinase inhibitors in cancer and autoimmune disease. Curr Opin Pharmacol 2012, I 2:464-70.

63. Scheinberg MA, Kay J: The advent of biosimilar therapies in rheumatology_-O brave new world”. Nat Rev Rheumatol 2012, 8:430-6.

\section{FlOOOPrime}

64. Kellner $\mathrm{H}$ : Targeting interleukin-I7 in patients with active rheumatoid arthritis: rationale and clinical potential. Ther Adv Musculoskelet Dis 2013, 5:141-52.

65. Baslund B, Trede N, Danneskiold-Samsoe B, Larsson P, Panayi G, Petersen J, Petersen LJ, Beurskens FJ, Schuurman J, van de Winkel JG, Parren PW, Gracie JA, Jongbloed S, Liew FY, Mclnnes IB: Targeting interleukin-I 5 in patients with rheumatoid arthritis: a proofof-concept study. Arthritis Rheum 2005, 52:2686-92.

66. Senolt $\mathrm{L}$ ea: “Improvements in patient-reported physical function, pain, and global disease activity in patients with rheumatoid arthritis after treatment with NNC0109-0012 (anti-IL-20 mAb) in a phase 2a trial" Abstract SATII2. In: EULAR 2013; Madrid, Spain.

67. Helling B, Daelken B, Wallmeier $\mathrm{H}$, Aigner S, Zuber $\mathrm{CH}$, Koenig $\mathrm{M}$, Engling $A$, Osterroth $F$, and $C N$, Uherek. C: The Therapeutic Antibody Tregalizumab (BT-06I) Induces Activation of Regulatory T Cells by Engaging a Unique CD4 Mediated Signaling That Strongly Differs From Signaling Events Induced by Standard Anti-CD4 Antibodies. In: ACR Annual Meeting: 2012; 2012.

68. Rudnev A, Ragavan S, Trollmo $C$ ea: Selective activation of naturally occurring regulatory $T$ cells (Tregs) by the monoclonal antibody (mAb) BT-06 I. Markers of clinical activity and early Phase II results in patients with rheumatoid arthritis (RA). In: American College of Rheumatology Annual Meeting 2010; 2010.

69. Genovese MC, Keystone E, Taylor $P$ ea: 24-week results of a blinded phase $2 b$ dose-ranging study of baricitinib, an oral janus kinase I/janus kinase 2 inhibitor, in combination with traditional disease modifying antirheumatic drugs in patients with rheumatoid arthritis. Arthritis Rheum 2012, 64:S1049-50.

70. Smolen JS, Schlichting DE, Sterling KL ea: I 2-and 24-week patientreported outcomes from a phase $\mathbf{2 b}$ dose-ranging study of baricitinib, an oral janus kinase I/janus kinase $\mathbf{2}$ inhibitor, in combination with traditional disease-modifying antirheumatic drugs in patients with rheumatoid arthritis. Arthritis Rheum 2012, 64:S2|4-20.

7I. Kyttaris VC: Kinase inhibitors: a new class of antirheumatic drugs. Drug Des Devel Ther 2012, 6:245-50.

\section{FlOOOPrime}

\section{RECOMMENDED}

72. Alten RE, Zerbini C, Jeka S, Irazoque F, Khatib F, Emery P, Bertasso A, Rabbia M, Caulfield JP: Efficacy and safety of pamapimod in patients with active rheumatoid arthritis receiving stable methotrexate therapy. Ann Rheum Dis 2010, 69:364-7.

73. Hirata S, Dirven L, Shen Y, Centola M, Cavet G, Lems WF, Tanaka Y, Huizinga TW, Allaart CF: A multi-biomarker score measures rheumatoid arthritis disease activity in the BeSt study. Rheumatology 2013, 52:1202-7.

\section{FlOOOPrime} RECOMMENDED

74. Hambardzumyan K, Bolce R, Cruickshank SE, Sasso EH, Chernoff D, Forslind K, Saevarsdottir S, Petersson IF, Geborek P, Ernestam S, van Vollenhoven RF: A Multi-Biomarker Disease Activity Score Correlates With Radiographic Progression In Early Rheumatoid Arthritis: Results From a Randomized Trial. In: $A C R$ Annual meeting: 2013; San Diego, USA; 2013. 